\title{
Mitochondrial Regulation of Cell Death
}

\author{
Stephen W.G. Tait ${ }^{1}$ and Douglas R. Green ${ }^{2}$ \\ ${ }^{1}$ Beatson Institute, Institute of Cancer Sciences, University of Glasgow, Glasgow G61 1BD, United Kingdom \\ ${ }^{2}$ Department of Immunology, St. Jude Children's Hospital, Memphis, Tennessee 38105 \\ Correspondence: stephen.tait@glasgow.ac.uk; douglas.green@stjude.org
}

\begin{abstract}
Although required for life, paradoxically, mitochondria are often essential for initiating apoptotic cell death. Mitochondria regulate caspase activation and cell death through an event termed mitochondrial outer membrane permeabilization (MOMP); this leads to the release of various mitochondrial intermembrane space proteins that activate caspases, resulting in apoptosis. MOMP is often considered a point of no return because it typically leads to cell death, even in the absence of caspase activity. Because of this pivotal role in deciding cell fate, deregulation of MOMP impacts on many diseases and represents a fruitful site for therapeutic intervention. Here we discuss the mechanisms underlying mitochondrial permeabilization and how this key event leads to cell death through caspase-dependent and -independent means. We then proceed to explore how the release of mitochondrial proteins may be regulated following MOMP. Finally, we discuss mechanisms that enable cells sometimes to survive MOMP, allowing them, in essence, to return from the point of no return.
\end{abstract}

In most organisms, mitochondria play an essential role in activating caspase proteases through a pathway termed the mitochondrial or intrinsic pathway of apoptosis. Mitochondria regulate caspase activation by a process called mitochondrial outer membrane permeabilization (MOMP). Selective permeabilization of the mitochondrial outer membrane releases intermembrane space (IMS) proteins that drive robust caspase activity leading to rapid cell death. However, even in the absence of caspase activity, MOMP typically commits a cell to death and is therefore considered a point of no return (Fig. 1). Because of this pivotal role in dictating cell fate, MOMP is highly regulated, mainly through interactions between pro- and antiapoptotic members of the $\mathrm{Bcl}-2$ family. In this article, we begin by discussing how mitochondria may have evolved to become central players in apoptotic cell death. We then provide an overview of current models addressing the mechanics of MOMP, outlining how this crucial event leads to cell death through both caspasedependent or -independent mechanisms. Finally, we discuss how caspase activity may be regulated post-MOMP and define other processes that allow cells to survive MOMP and, in effect, return from the point of no return.

\section{MITOCHONDRIA-NATURAL-BORN KILLERS?}

The endosymbiosis theory of evolution posits that mitochondria are modern-day descendants

Editors: Eric H. Baehrecke, Douglas R. Green, Sally Kornbluth, and Guy S. Salvesen

Additional Perspectives on Cell Survival and Cell Death available at www.cshperspectives.org

Copyright (C) 2013 Cold Spring Harbor Laboratory Press; all rights reserved; doi: 10.1101/cshperspect.a008706

Cite this article as Cold Spring Harb Perspect Biol 2013;5:a008706 
S.W.G. Tait and D.R. Green

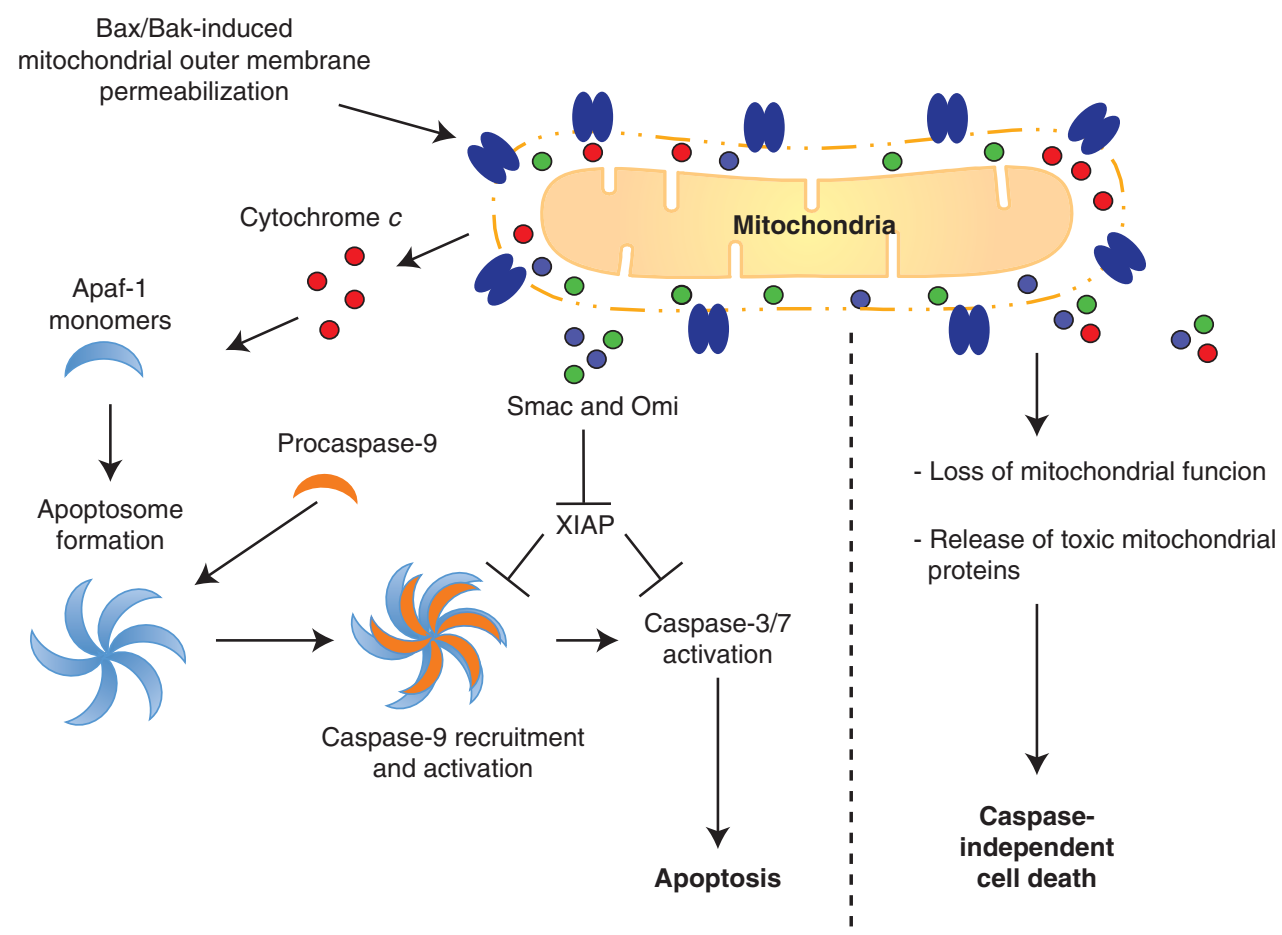

Figure 1. Mitochondrial regulation of cell death. Bax/Bak-mediated mitochondrial outer membrane permeabilization (MOMP) can lead to caspase-dependent apoptosis (left) or caspase-independent cell death (right). Following MOMP, soluble proteins are released from the mitochondrial intermembrane space into the cytoplasm. Cytochrome $c$ binds to monomeric Apaf-1 leading to its conformational change and oligomerization. Procaspase- 9 is recruited to heptameric Apaf- 1 complexes forming the apoptosome. This leads to activation of caspase- 9 and, through caspase-9-mediated cleavage, activation of the executioner caspases- 3 and -7. Release of Smac and Omi from the mitochondrial intermembrane space facilitates caspase activation by neutralizing the caspase inhibitor XIAP. MOMP can also lead to nonapoptotic cell death through a gradual loss of mitochondrial function and/or release of mitochondrial proteins that kill the cell in a caspase-independent manner.

of $\alpha$-proteobacteria that invaded archeon cells more than 2 billion years ago (Gray 2012). This invasion, ultimately forming the original eukaryotic cell, may have simultaneously forged a role for mitochondria in cell death. One possibility is that, following bacterial invasion, the archeon underwent altruistic cell death in order to protect the clonal population (James and Green 2002; Green 2011). Over time, some bacteria may have been able to prevent cell death, forming an endosymbiotic relationship with the archeon and eventually giving rise to mitochondria as we know them today. It may be that Bcl-2 proteins are modern-day descendants of toxins expressed by bacteria to kill one another that were initially co-opted to enable permeabili- zation of the mitochondrial outer membrane (which is likely host cell-derived, based on composition) while sparing the mitochondrial inner membrane (which resembles bacterial membrane composition). Accordingly, Bcl-2 proteins display structural similarities to certain bacterial toxins including diphtheria toxin $\beta$ chain and the colicins (Muchmore et al. 1996; Suzuki et al. 2000). Over time, as with most mitochondrial functions, genetic control of the proteins that regulate cell death may have transferred to the nucleus, whereas the mitochondrial outer membrane remains the battlefield.

Mitochondria play a role in apoptosis in most animals; however, the extent and importance of their contribution differs greatly be- 
tween organisms (Oberst et al. 2008). In mammals, the essential requirement for MOMP as an initiating event in caspase activation and apoptosis is best evidenced in mice lacking Bax and Bak (Lindsten et al. 2000; Wei et al. 2001). Cells derived from these mice are profoundly resistant to all intrinsic apoptotic stimuli, and Bax/Bak double-knockout mice display developmental defects consistent with inhibition of cell death. In stark contrast, in the nematode Caenorhabditis elegans or the fly Drosophila melanogaster, two organisms that have been used extensively in cell death research, mitochondria do not appear to play a major role in the activation and execution of apoptosis. In Caenorhabditis elegans, although the proteins that control caspase activation are located on the mitochondria, this localization is not required for the regulation of apoptosis (Tan et al. 2007). In D. melanogaster, neither mitochondria nor Bcl-2 homologs regulate caspase activation. Instead, caspase activity is regulated primarily through interactions between caspases and inhibitor of apoptosis (IAP) proteins (Ryoo and Baehrecke 2010). Importantly, MOMP does not occur in C. elegans apoptotic cell death, and although MOMP has been observed during apoptosis in D. melanogaster, this is a consequence rather than a cause of caspase activation (Abdelwahid et al.2007). This has led to the prevalent opinion that MOMP-dependent regulation of apoptosis evolved in higher eukaryotes. However, recent findings challenge this view; in the lophotrochozoan invertebrate Planaria (phylum Platyhelminthes), proapoptotic stimuli induce MOMP, and planarian caspases can be activated in cytosols by cytochrome $c$ (unlike D. melanogaster or C. elegans caspases) (Bender et al. 2012). Planaria also encode a proapoptotic Bak homolog that can directly induce MOMP. Similarly, schistosomes (phylum Helminthes) also encode $\mathrm{Bcl}-2$ proteins that can regulate MOMP (Lee et al. 2011). Cytochrome $c$ can also activate caspases from an invertebrate deuterostome, the purple sea urchin, Strongylocentrotus purpuratus (phylum Echinodermata) (Bender et al. 2012). Collectively, these findings argue that, in cell death terms, D. melanogaster and C. elegans may be evolutionary outliers and that MOMP may be the primordial and predominant means of caspase activation in animals.

\section{UNLEASHING THE DEATH SQUAD: MOLECULAR MECHANISMS OF MOMP}

Because MOMP dictates cells fate, it is highly regulated, largely through interactions between pro- and antiapoptotic Bcl-2 family members (Youle and Strasser 2008). How antiapoptotic $\mathrm{Bcl}-2$ proteins regulate MOMP is discussed elsewhere-here we review how the proteins that are required for MOMP, Bax and Bak, are activated and how, upon activation, they permeabilize the mitochondrial outer membrane.

Following activation by direct interaction with $\mathrm{BH} 3$-only $\mathrm{Bcl}-2$ proteins, Bax and Bak undergo dramatic structural changes leading to mitochondrial targeting of Bax (which is predominantly cytosolic when inactive) and homo-oligomerization of Bax and Bak (Hsu et al. 1997; Eskes et al. 2000; Wei et al. 2000). Oligomerization of Bax and Bak is essential for MOMP because mutants that fail to oligomerize are completely inactive (George et al. 2007; Dewson et al. 2008). Given their pivotal role in deciding whether a cell dies or not, the mechanisms underlying Bax and Bak activation have been intensively investigated; however, it remains contentious how these proteins drive MOMP (Fig. 2). One model proposes that Bax is activated by $\mathrm{BH} 3$-only proteins, not by binding in the hydrophobic BH3-binding pocket of Bax (which might be expected) but rather by interacting on the opposite side of Bax (Gavathiotis et al. 2008, 2010). Activated Bax then self-propagates further activation through its own, newly exposed BH3-only domain. This leads to the formation of asymmetric Bax oligomers that ultimately cause MOMP. Alternatively, $\mathrm{BH} 3$ proteins can activate $\mathrm{Bax}$ and Bak by binding in their hydrophobic $\mathrm{BH} 3$-binding pockets (Czabotar et al. 2013; Leshchiner et al. 2013; Moldoveanu et al. 2013). Upon activation, Bax and Bak homodimerize in a head-to-head manner (Dewson et al. 2008, 2012). Dimerization unveils a cryptic dimer-dimer binding site that allows oligomers of homodimers to form and cause MOMP (Dewson et al. 2009). 
S.W.G. Tait and D.R. Green

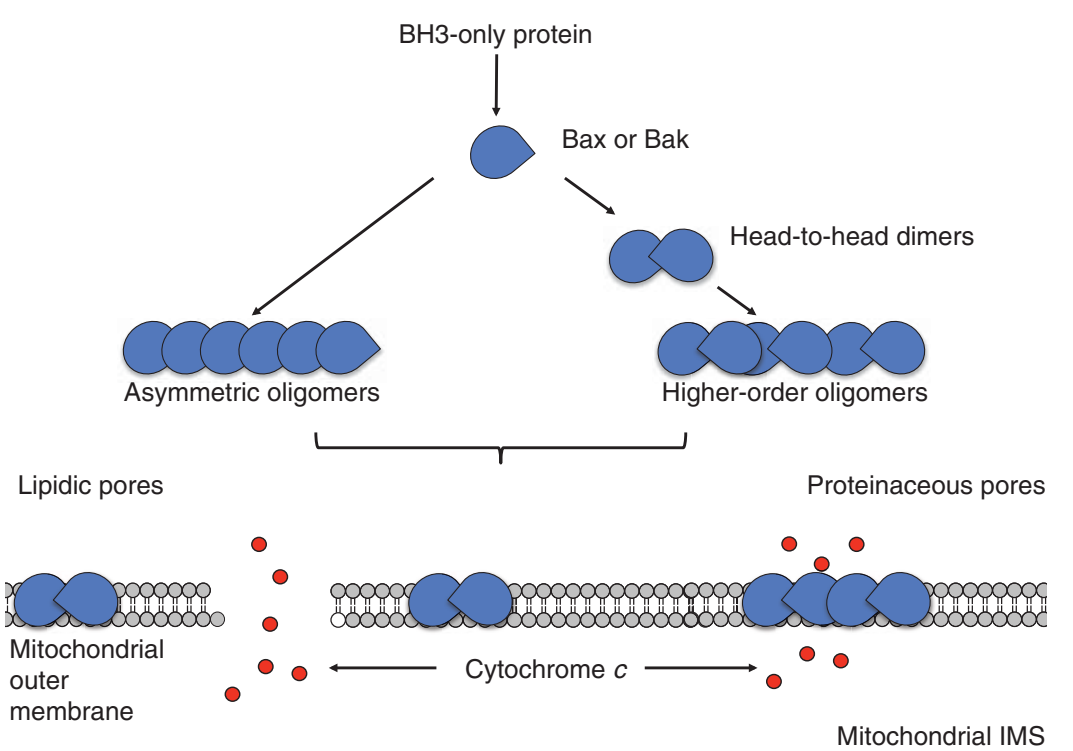

Figure 2. Mechanism of Bax/Bak activation and MOMP. BH3 domain-only proteins directly bind and activate Bax and Bak. Activated Bax and Bak form higher-order oligomers, either through asymmetric oligomers (Bax) or through the formation of higher-order oligomers formed by head-to-head Bax or Bak dimers. How oligomeric Bax and Bak permeabilize the mitochondrial outer membrane is unclear. Two prominent models argue that Bax and Bak do this either by inducing lipidic pores (left) or by directly forming proteinaceous pores (right).

Initial live-cell imaging studies, using cytochrome $c$ GFP to report mitochondrial permeabilization, showed that, although the onset of MOMP is highly variable, following its initiation, permeabilization of mitochondria occurs in a rapid $(<5 \mathrm{~min})$ and complete manner (Goldstein et al. 2000). More recently, several studies have found that MOMP can occur at a defined point or points within a cell and propagate in a wave-like fashion over the whole cell (Lartigue et al. 2008; Bhola et al. 2009; Rehm et al. 2009). Exactly how these waves are propagated is unclear, but existing data argue against involvement of either caspases or the mitochondrial permeability transition, a change in the inner mitochondrial membrane permeability to small solutes (Crompton 1999). As discussed previously, the self-propagating nature of Bax and Bak activation might be expected to facilitate the occurrence of MOMP in a wave-like manner. Chemical inhibitors of casein kinase II inhibit wave formation, arguing that substrate(s) of this kinase (perhaps BH3-only proteins) are relevant for wave formation (Bhola et al. 2009). Alternatively, mitochondrial-derived reactive oxygen species (ROS) may promote wave formation because inhibition of ROS or addition of ROS scavengers prevents wave-like MOMP from occurring (Garcia-Perez et al. 2012). It remains unclear how permeabilization of individual mitochondria generates ROS, or, indeed, what the targets of ROS are that facilitate wave propagation.

Much interest has focused on whether MOMP permits selective or nonselective release of mitochondrial intermembrane space (IMS) proteins. At least in vitro, Bax-mediated permeabilization of liposomes leads to release of $10-\mathrm{kDa}$ and 2-MDa dextrans with similar kinetics (Kuwana et al. 2002). In cells, proteins $>100 \mathrm{kDa}$ (predicted molecular weight of Smac-GFP dimers) are released with kinetics similar to cytochrome $c$; however, a Smac dsRed tetrameric fusion protein (predicted size $190 \mathrm{kDa}$ ) failed to be released from mitochondria upon MOMP (Rehm et al. 2003). Furthermore, ectopic expression of XIAP delays the kinetics of Smac release following MOMP from 
mitochondria dependent on the ability of XIAP to enter the mitochondrial IMS and complex with Smac (Flanagan et al. 2010). Although these results suggest that the release of IMS proteins following MOMP may have size limitations in vivo, the onset of IMS protein release from mitochondria is the same irrespective of size, thus arguing that all soluble IMS proteins exit the mitochondria through a similar mechanism (Munoz-Pinedo et al. 2006). In some settings, selective release of mitochondrial IMS proteins can be observed; for example, cells deficient in Drp-1, a dynamin-like protein required for mitochondrial fission, preferentially release Smac but not cytochrome $c$ following MOMP (Parone et al. 2006; Estaquier and Arnoult 2007; Ishihara et al. 2009). Why loss of Drp-1 selectively inhibits cytochrome $c$ egress from the mitochondria remains unclear, but this can inhibit the kinetics of caspase activation and apoptosis. Interestingly, Drp- 1 can also act as a positive regulator of Bax-mediated MOMP (Montessuit et al. 2010).

The requirement for Bax and Bak in MOMP is clear, but how these proteins actually permeabilize the mitochondrial outer membrane remains elusive. Two prominent models propose that activated Bax and Bak cause MOMP either by forming proteinaceous pores themselves or, alternatively, by causing the formation of lipidic pores in the mitochondrial outer membrane. As discussed above, pro- and antiapoptotic $\mathrm{Bcl}-2$ proteins are structurally similar to bacterial pore-forming toxins, implying that Bax and Bak themselves might directly form pores in the mitochondrial outer membrane (Muchmore et al. 1996; Suzuki et al. 2000). Along these lines, several studies have found that Bax can induce ion channels in artificial membranes; however, somewhat confusingly, antiapoptotic Bcl2 proteins can also form membrane pores (Antonsson et al. 1997). Patch-clamp studies of isolated mitochondria have discovered that during MOMP (initiated by the addition of the $\mathrm{BH} 3$-only protein $\mathrm{tBid}$ ), a mitochondrial outer membrane channel forms that increases with size over time and displays kinetics similar to MOMP (Martinez-Caballero et al. 2009). This implies that the channel (termed the mitochon- drial apoptosis-induced channel [MAC]) as the perpetrator of MOMP. In support of this, inhibitors that block MAC block MOMP and apoptosis in cells (Peixoto et al. 2009). However, it remains possible that these inhibitors block the initial activation of Bax and Bak. Furthermore, in the majority of studies, the size of the MAC channels detected have only been large enough to accommodate cytochrome $c$ release, but, as discussed above, MOMP clearly allows for the release of much larger proteins.

An alternative model proposes that activated Bax and Bak cause MOMP by inducing lipidic pores. This model would account for various characteristics of MOMP including the release of large IMS proteins and a consistent inability to detect proteinaceous pores in the mitochondrial outer membrane. Activated Bax can induce liposome permeabilization in vitro, leading to the release of encapsulated material in a size-independent manner, thereby recapitulating a key characteristic of MOMP (Basanez et al. 1999, 2002; Hardwick and Polster 2002). Moreover, cryo-EM analysis of Bax-permeabilized liposomes revealed large openings (up to $100 \mathrm{~nm}$ ). These appeared concurrently with permeabilization and could be inhibited in a Bcl- $\mathrm{X}_{\mathrm{L}}$-dependent manner (Schafer et al. 2009). In further support of the lipidic pore model, Bax-induced pores were variable in size and lacked proteinaceous material-this contrasts with protein pores formed by the bacterial toxin pneumolysin that are uniform in nature and proteinaceous in composition. However, whether activated Bax and Bak induce MOMP by forming lipid pores in mitochondrial outer membranes remains unclear because similar pore-like structures have not been observed in mitochondria.

\section{APPETITE FOR DESTRUCTION: HOW MOMP KILLS CELLS}

Irrespective of mechanism, MOMP wreaks havoc on the cell. Normally, MOMP leads to the release of proteins that activate caspases leading to rapid, apoptotic cell death. However, even in the absence of caspase activity, cells generally succumb to cell death through an ill-defined process termed caspase-independent cell death 
S.W.G. Tait and D.R. Green

(CICD) (Tait and Green 2008) (Fig. 1). Therefore, MOMP is often considered a point of no return. Here we review how MOMP triggers cell death through caspase-dependent and -independent means.

\section{Mitochondrial-Dependent Caspase Activation}

Although the onset of MOMP is highly variable, following mitochondrial permeabilization, caspases are activated in a robust manner leading to apoptosis typically within a few minutes (Goldstein et al. 2000; Albeck et al. 2008). Of the many mitochondrial intermembrane space proteins released following MOMP, cytochrome $c$ is the most important. Once in the cytoplasm, cytochrome $c$ transiently binds the key caspase adaptor molecule Apaf-1. This interaction triggers extensive conformational changes in Apaf-1 leading to its oligomerization into a heptameric wheel-like structure and exposure of caspase activation and recruitment domains (CARD) (Bratton and Salvesen 2010). The Apaf-1 CARD domains bind to CARD domains of the initiator caspase procaspase-9, forming the apoptosome. At the apoptosome, dimerization of caspase- 9 leads to its activation, which, in turn, cleaves and activates the executioner caspases-3 and -7 , leading to rapid cell death. Cytochrome $c$ is essential for mitochondrial-dependent caspase activation; cells that lack cytochrome $c$ or express a mutant that poorly activates Apaf-1 (but retains respiratory function) fail to activate caspases following MOMP (Li et al. 2000; Hao et al. 2005; Matapurkar and Lazebnik 2006). Moreover, mice expressing this mutated form of cytochrome $c$ phenocopy the neurological defects observed in Apaf-1- and caspase-9-deficient mice.

Besides cytochrome $c$, other mitochondrial IMS proteins facilitate caspase activation. These include Smac (also called Diablo) and Omi (also called HtrA2) (Du et al. 2000; Verhagen et al. 2000; Suzuki et al. 2001). Both proteins reside in the mitochondrial intermembrane space and are released following MOMP. In healthy cells, Omi functions as a mitochondrial chaperone, whereas the nonapoptotic function for Smac is not known. Smac and Omi promote caspase activation by binding to and neutralizing the caspase inhibitor XIAP. However, in contrast to cytochrome $c$, loss of either Omi or Smac either individually or together does not impart resistance to caspase activation and apoptosis (Okada et al. 2002; Jones et al. 2003; Martins et al. 2004). Indeed, likely because of its chaperone function, cells and mice lacking Omi are rendered more sensitive to mitochondrial damage and cell death. Although these results argue that XIAP neutralization may facilitate rather than be essential for caspase activation, recent data argue that in death-receptor-triggered apoptosis, neutralization of XIAP is essential for effective caspase activation in type II cells (cells that require MOMP for deathreceptor-induced apoptosis) (Jost et al. 2009). Moreover, there may be significant redundancy with respect to XIAP inhibition given the identification of various other mitochondrial proteins that can inhibit XIAP (Zhuang et al. 2013).

Other mitochondrial IMS proteins that have been proposed to facilitate caspase activation include apoptosis-inducing factor (AIF). In contrast to cytochrome $c$, the release of AIF from the mitochondrial IMS following MOMP is slow and, in some circumstances, caspase-dependent (Arnoult et al. 2003; Munoz-Pinedo et al. 2006). As such, AIF likely does not seem to play a major role in apoptosis induction.

Even in the absence of caspase activity, cells typically succumb to a slower, ill-defined form of death termed caspase-independent cell death (CICD). CICD may serve primarily as a failsafe mechanism to ensure that cell death occurs even if caspases are inhibited (e.g., by a viral caspase inhibitor). Careful morphological analysis revealed that under physiological conditions, CICD may account for up to $10 \%$ of cell death-if this is, indeed, the case, it represents a major cell death modality (Chautan et al. 1999). Furthermore, comparison of early embryonic lethality (typically embryonic day 7 [E7], although some survive and can mature to adulthood) observed with Bax/Bak-deficient mice (unable to undergo MOMP) with the postnatal lethality of Apaf-1-deficient mice (can only undergo CICD) argues that, at the gross level, 
Mitochondrial Regulation of Cell Death

CICD can effectively substitute for apoptosis, at least during development (Yoshida et al. 1998; Lindsten et al. 2000). That said, the $\sim 15 \%$ of Bax/Bak-deficient animals that survive embryogenesis and mature, showing some neurological defects and expansion of lymphoid cells, represents an ongoing puzzle for the role of MOMP in development.

How CICD occurs following MOMP is unclear. Indeed, the mechanism of CICD may vary in a cell-type-dependent manner-unlike the canonical, mitochondrial pathway of caspase activity. One model supports an active role for mitochondria in mediating cell death, for example, through the release of proteins following MOMP such as AIF that can actively induce CICD. AIF may contribute to caspase-independent cell death (CICD) in some settings (Cheung et al. 2006). Alternatively, CICD may be mediated primarily by mitochondrial dysfunction that ensues following MOMP, ultimately leading to metabolic catastrophe and cell death. Along these lines, analysis of cells undergoing CICD found a rapid reduction in mitochondrial respiratory complex I and IV function (Lartigue et al. 2009). At subsequent time points post-MOMP, cytochrome $c$ can be targeted for proteasome-dependent degradation, again promoting respiratory dysfunction (Ferraro et al. 2008). In addition to breakdown of mitochondrial respiratory function, mitochondrial proteins including TIM23 (an essential component of the mitochondrial inner membrane translocase complex) can be cleaved and inactivated following MOMP, in doing so contributing to mitochondrial dysfunction (Goemans et al. 2008). Moreover, given the important role that AIF has in maintaining respiratory complex I function (Vahsen et al. 2004), loss of AIF from the mitochondria should also promote mitochondrial dysfunction. Collectively, these findings argue that loss of mitochondrial function may be the principle reason that cells die through CICD following MOMP. However, because cells can survive complete removal of mitochondria for at least $4 \mathrm{~d}$, which is typically longer than the kinetics of CICD, this still suggests that permeabilized mitochondria may also play an active role in CICD (Narendra et al. 2008). One such role may be as "ATPsinks" because maintenance of the transmembrane potential is sustained by reversal of the $\mathrm{F}_{0} \mathrm{~F}_{1}$ ATPase.

\section{POST-MOMP REGULATION OF CASPASE ACTIVITY}

Under some circumstances, MOMP need not be a death sentence. However, in order to evade cell death post-MOMP, cells must limit caspase activation. Here we review mechanisms of caspase activity regulation after MOMP, focusing on regulation of IMS protein release following MOMP and direct means of inhibiting caspase activation following mitochondrial permeabilization.

\section{Post-MOMP Regulation of IMS Protein}

Release

MOMP itself does not appear to afford any specificity over which IMS proteins are released from the mitochondria. However, various studies implicate mechanisms that govern selective release of IMS proteins following MOMP; principally, these mechanisms center on IMS protein interaction with the mitochondrial membranes or by remodeling of the mitochondrial inner membrane (Fig. 3).

AIF is tethered to the mitochondrial inner membrane; consequently, its release following MOMP requires proteolytic cleavage either by caspase or calpain proteases (Arnoult et al. 2003; Polster et al. 2005). In the case of cytochrome $c$, electrostatic interactions with inner membrane lipids and the oxidative state of these lipids (where oxidized lipids bind cytochrome $c$ less) have been proposed to regulate its release following MOMP (Ott et al. 2002).

The mitochondrial inner membrane is largely composed of cristae, involutions that greatly expand the mitochondrial surface area for oxidative phosphorylation and ATP generation. Far from being static, cristae are highly dynamic structures, and their accessibility to the IMS is regulated through cristae junctions. Interestingly, most cytochrome $c$ resides in mitochondrial cristae, leading various studies to 
S.W.G. Tait and D.R. Green

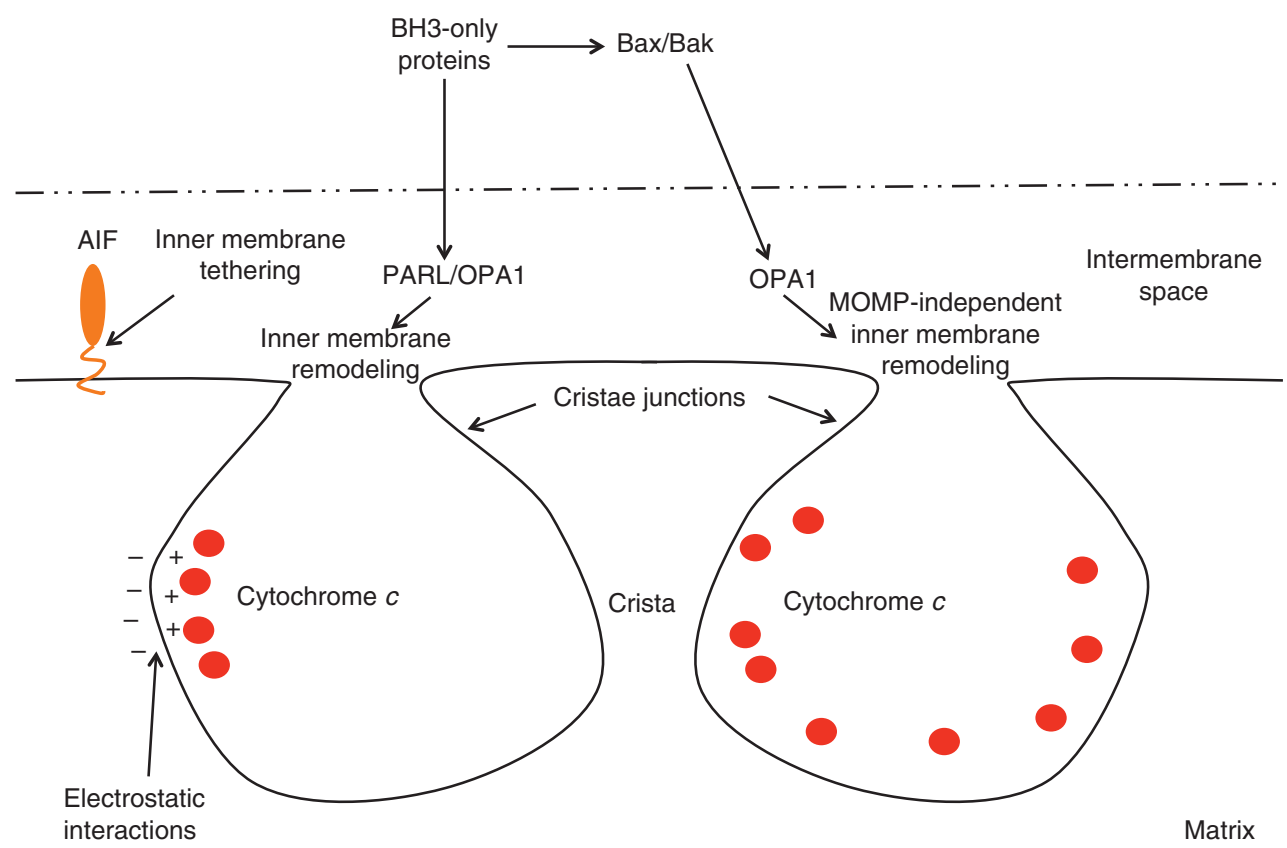

Figure 3. Post-MOMP regulation of mitochondrial intermembrane space protein release. The intermembrane space protein AIF is tethered to the mitochondrial inner membrane and requires cleavage to liberate it from the mitochondria upon MOMP. The majority of cytochrome $c$ is sequestered within mitochondrial cristae; electrostatic interactions facilitate its association with the inner membrane. Some studies argue that cristae remodeling must occur to allow cytochrome $c$ egress from the mitochondrial cristae following MOMP. Cristae remodeling can occur in a MOMP-independent manner by $\mathrm{BH} 3$ proteins (in a Bax/Bak-independent manner) or by activated Bax and Bak. Remodeling is dependent upon the intermembrane space rhomboid protease PARL and the dynamin-like GTPase OPA1.

address whether cristae remodeling provides an additional layer of regulating cytochrome $c$ release from the mitochondria. Accordingly, several BH3-only proteins including Bid, Bim, BNIP3, and Bik have been found to regulate cristae remodeling (Scorrano et al. 2002; Germain et al. 2005; Yamaguchi et al. 2008). In vitro treatment of mitochondria with the $\mathrm{BH} 3$ protein tBid leads to extensive remodeling, interconnected cristae, and cytochrome $c$ mobilization from the cristae into the IMS. Interestingly, this effect of tBid on mitochondrial inner membrane dynamics did not require the $\mathrm{tBid} \mathrm{BH} 3$ domain (Scorrano et al. 2002). Other studies have found that membrane remodeling requires active Bax and Bak but does not necessitate MOMP, because pharmacological inhibitors of MOMP still allow remodeling (Yamaguchi et al. 2008). Two IMS proteins, OPA1 (a dynamin- like GTPase) and PARL (a rhomboid protease), are essential for regulating cristae dynamics. Upon MOMP, disruption of OPA1 oligomers widens cristae junctions, whereas PARL cleavage of OPA1 generates a cleavage product that maintains tight junctions (Frezza et al. 2006). However, other studies have found no gross changes in mitochondrial morphology or cristae junction size upon MOMP or only detected them following executioner caspase activitythis argues that remodeling may be consequential rather than causative in promoting IMS protein release (Sun et al. 2007). Moreover, even in a closed state, cytochrome $c$ should be able to exit cristae junctions, arguing that cristae width is not a key determinant of release in itself (Gillick and Crompton 2008). Possibly, cristae remodeling may support IMS protein release in a cell-type-specific manner, or OPA1 and PARL 
may facilitate IMS protein release independently of cristae remodeling.

Besides regulating IMS protein release postMOMP, a plethora of mechanisms have been described that can limit caspase activity. The physiological role of these mechanisms is uncertain, but perhaps they serve to restrain caspase activity and allow viability should MOMP occur in a limited number of mitochondria. As discussed above, through a well-described mechanism, XIAP can limit caspase activation by binding active caspases- $9,-3$, and -7 . However, additional direct and indirect means of regulating caspase activity also exist that center on the formation and activation of the apoptosome. Importantly, various means of inhibiting apoptosome activation have been described in cancer, implying that this may facilitate cancer cell survival (Schafer and Kornbluth 2006).

Apoptosome Formation: Regulating the Wheel of Misfortune

Formation of the apoptosome is essential for efficient caspase- 9 activation and mitochondrial-dependent apoptosis. APAF1 must bind dATP for apoptosome formation; however, paradoxically, physiological levels of nucleotides inhibit apoptosis by directly binding cytochrome $c$, preventing it from binding APAF1 (Chandra et al. 2006) (Fig. 4). Similarly, transfer RNA (tRNA) has also been found to bind cytochrome $c$, blocking its interaction with APAF1 and thereby preventing apoptosome formation (Mei et al. 2010). Physiological levels of potassium and calcium also inhibit cytochrome $c$ induced apoptosome formation (Cain et al. 2001; Bao et al. 2007). These inhibitory mechanisms may primarily exist to suppress accidental MOMP-induced caspase activity but are overwhelmed following rapid and extensive mitochondrial release of cytochrome $c$ during apoptosis.

The redox status of a cell may also affect the proapoptotic activity of cytochrome $c$ where oxidation promotes its proapoptotic activity and reduction inhibits it (Pan et al. 1999; Borutaite and Brown 2007). Mechanistically, how redox status would affect the ability of cytochrome $c$ to induce apoptosome formation remains unclear, and some studies have found that reduced cytochrome $c$ can still effectively activate caspases in vitro (Kluck et al. 1997). Various other proteins including HSP70, HSP90, and Cdc6 have been found to inhibit apoptosome function either by blocking its assembly or by inhibiting binding and activation of procaspase- 9 at the apoptosome (Beere et al. 2000; Pandey et al. 2000; Saleh et al. 2000; Niimi et al. 2012).

Apoptosome function can also be positively regulated. The protein PHAP1 (also known as pp32) enhances apoptosome function by inhibiting aggregation of APAF1 and promoting nucleotide exchange (Jiang et al 2003; Kim et al. 2008). Importantly, reduced levels of PHAP1 inhibit apoptosis and allow clonogenic survival following chemotherapy - this finding may be relevant in small cell lung cancer because reduced PHAP expression correlates with poor clinical response to chemotherapy (Hoffarth et al. 2008).

\section{Regulating Caspase-9 Activation}

In addition to regulation of apoptosome assembly, caspase- 9 activity can also be regulated. Several kinases can phosphorylate caspase-9 and inhibit its enzymatic activity. These include the MAP kinases ERK1 and ERK2 and CDK1cyclin B1 (Allan et al. 2003; Allan and Clarke 2007). Although it is clear that phosphorylation can inhibit caspase- 9 activity, how it achieves this is not understood. Because recruitment of procaspase- 9 to the apoptosome does not appear to be affected by phosphorylation, perhaps phosphorylation of caspase- 9 blocks its ability to dimerize. Interestingly, Rsk kinase (also a member of the MAPK family) has been found to inhibit Apaf-1 function by direct phosphorylation (Kim et al. 2012). This enables the adaptor protein 14-3-3e; to bind Apaf-1 and prevent apoptosome assembly. At the apoptosome, autoprocessing of caspase- 9 leads to a dramatic reduction in its affinity for the apoptosome, resulting in loss of caspase- 9 activity. This mechanism acts as a "molecular timer" of which its activity (and ability to drive executioner caspase activity) is dictated by intracellular caspase- 9 
S.W.G. Tait and D.R. Green

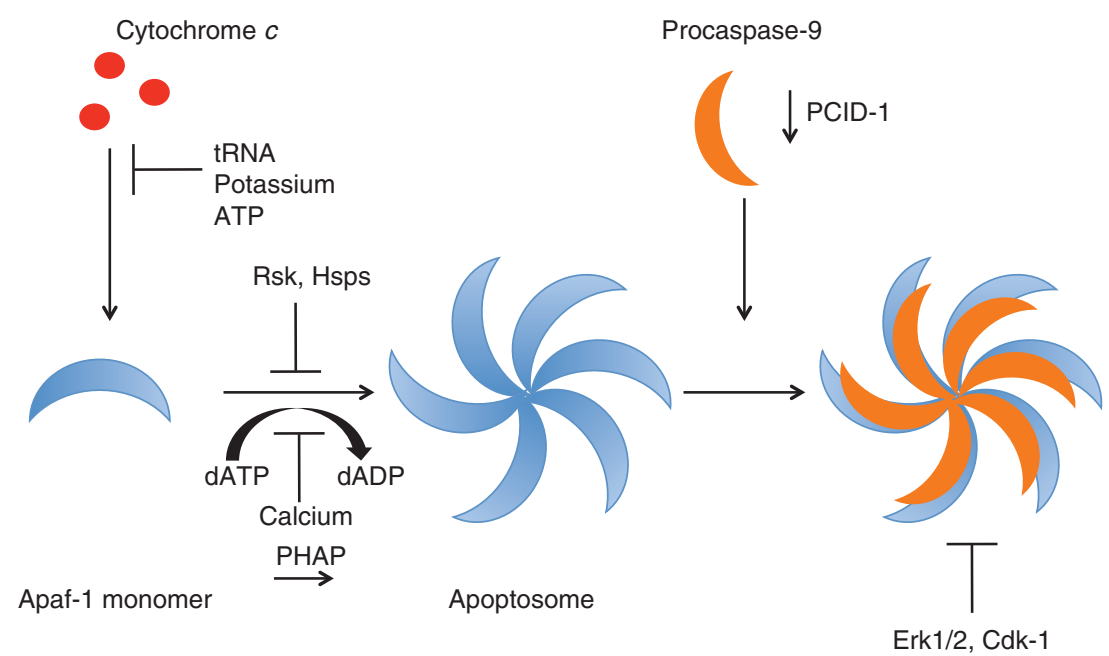

Figure 4. Regulation of apoptosome activity. Various molecules, including tRNA, potassium, and ATP, can competitively inhibit cytochrome $c$-Apaf-1 interactions, thereby blocking apoptosome formation. Apaf-1 oligomerization can be positively affected by proteins such as PHAP that facilitate nucleotide exchange, whereas intracellular calcium levels inhibit this event. Various proteins, including heat shock proteins (Hsps) and kinases such as Rsk can directly inhibit Apaf-1 oligomerization through interaction with Apaf-1 or by inhibitory phosphorylation. The activity of the apoptosome can also be inhibited by the kinase activity of Erk1/2 and Cdk-1. Finally, proteins such as PCID1 can regulate the intracellular levels of procaspase-9, thereby regulating apoptosome activity.

levels (Malladi et al. 2009). Consequently, regulation of caspase- 9 expression can also control caspase activity post-MOMP. PCID1 is the human ortholog of Tango7, a D. melanogaster protein that regulates expression of the initiator caspase pro-Dronc (Chew et al. 2009). In an analogous manner, down-regulation of PCID1 reduces expression of procaspase-9. This may be clinically relevant because PCID1 is frequently down-regulated in pancreatic cancer (Jones et al. 2008).

\section{DODGING THE BULLET-CELL SURVIVAL FOLLOWING MOMP}

Although MOMP often represents a point of no return, this is not always the case. Cell survival following MOMP likely has important pathophysiological functions by facilitating longterm survival of postmitotic cells and enabling tumor cell survival. Moreover, MOMP itself may have noncytotoxic signaling functions, thereby requiring cells to survive this process. Here we discuss how cells survive MOMP and the roles, both good and bad, that survival postMOMP can have.

\section{Surviving "Accidental" MOMP}

Live-cell imaging studies led to the initial view that MOMP is an all-or-nothing event (Goldstein et al. 2000). However, subsequent work has found that MOMP can sometimes be incomplete, leaving a minority of mitochondria intact (Tait et al. 2010). This suggests that the converse could also occur; limited mitochondria may undergo permeabilization without leading to cell death. Such accidental MOMP would necessitate that a threshold extent of MOMP must be crossed in order to trigger apoptotic caspase activity. Indeed, laser irradiation of neuronal mitochondria leading to MOMP of $15 \%$ of a cell's mitochondria was insufficient to trigger MOMP (Khodjakov et al. 2004). As already discussed, there are a plethora of mechanisms that can restrain caspase activity post-MOMP, but whether MOMP does occur in a few mitochondria without triggering cell death remains unknown. 


\section{Postmitotic Cell Survival}

The life-long requirement of postmitotic cells necessitates robust prosurvival mechanisms. Both sympathetic neurons and cardiomyocytes can survive MOMP, at least in part, because they express insufficient levels of APAF-1 to activate caspases efficiently (Wright et al. 2004; Potts et al. 2005). XIAP is also a major player in conferring nonresponsiveness to MOMP in these cell types because addition of SMAC or deletion of XIAP can restore apoptotic sensitivity (Potts et al. 2003). In the case of neurons, NGF deprivation induces a so-called competence to die because it leads to XIAP down-regulation (Deshmukh and Johnson 1998; Martinou et al. 1999). Besides XIAP, the high glycolytic levels of neurons also facilitate inhibition of caspase activity (Vaughn and Deshmukh 2008). Glycolysis leads to increased glutathione synthase levels through the pentose phosphate shunt. As discussed above, reduction of cytochrome $c$ can impair its ability to induce apoptosome activation. Comparable inhibitory mechanisms may also play a role in tumor cells given that they too are highly glycolytic.

\section{Recovery from MOMP in Dividing Cells}

In some situations, proliferating cells can survive MOMP provided that caspase function is inhibited. This has the potential to have an impact on both tumor development and therapeutic responses because cancer cells often inhibit caspase activity downstream from MOMP by a variety of mechanisms. Through a retroviralbased cDNA screen, GAPDH was found to protect cells from caspase-independent cell death downstream from MOMP (Colell et al. 2007). This protective role of GAPDH was due both to its well-established role as a key glycolytic enzyme and a newly described function by upregulating autophagy. The ability of GAPDH to promote cell survival may be important in BCR-ABL-dependent chronic myeloid leukemia because GAPDH can promote resistance to cell death induced by BCR-ABL inhibitors (Lavallard et al. 2009).

Numerous events must occur in order for a cell to survive MOMP. Permeabilized mito- chondria must be repaired or removed, and "new" mitochondria must be generated. Mitochondrial repopulation requires a cohort of mitochondria that fail to permeabilize following MOMP. The ability of certain mitochondria to evade MOMP relates to increased levels of antiapoptotic Bcl-2 proteins on their outer membrane; accordingly, Bcl-2 antagonist drugs can effectively permeabilize these mitochondria. Together with the strong correlation observed between the presence of intact mitochondria and cell survival, this suggests that the intact mitochondria provide a seed population of healthy mitochondria that ultimately repopulate the cell (Tait et al. 2010).

\section{SUMMARY}

Our understanding of MOMP and how it triggers cell death has advanced to the stage that drugs have now been developed to target this process. Nevertheless, significant gaps in our knowledge exist. For example, how activated Bax and Bak permeabilize the mitochondrial outer membrane is unknown. Secondly, although we understand how MOMP drives caspase activation, we have little mechanistic insight as to how it leads to CICD. The extent to which cells undergo CICD in vivo is difficult to gauge, mainly because of the lack of tools to detect and quantify this form of cell death accurately. Furthermore, although poorly understood, much greater attention is now being paid to how the mode of cell death influences the way the immune system perceives and reacts to a dying cell. Last, as we have discussed, MOMP need not be a death sentence. However, the mechanisms that allow cells to recover from MOMP remain poorly defined, as do its in vivo occurrence and pathophysiological importance. Ultimately, further understanding of how MOMP dictates life and death will facilitate its therapeutic targeting in a variety of diseases.

\section{ACKNOWLEDGMENTS}

S.W.G.T. is a Royal Society University Research Fellow. 
S.W.G. Tait and D.R. Green

\section{REFERENCES}

Abdelwahid E, Yokokura T, Krieser RJ, Balasundaram S, Fowle WH, White K. 2007. Mitochondrial disruption in Drosophila apoptosis. Dev Cell 12: 793-806.

Albeck JG, Burke JM, Aldridge BB, Zhang M, Lauffenburger DA, Sorger PK. 2008. Quantitative analysis of pathways controlling extrinsic apoptosis in single cells. Mol Cell 30: $11-25$.

Allan LA, Clarke PR. 2007. Phosphorylation of caspase-9 by $\mathrm{CDK1}$ /cyclin B1 protects mitotic cells against apoptosis. Mol Cell 26: 301-310.

Allan LA, Morrice N, Brady S, Magee G, Pathak S, Clarke PR. 2003. Inhibition of caspase- 9 through phosphorylation at Thr 125 by ERK MAPK. Nat Cell Biol 5: 647-654.

Antonsson B, Conti F, Ciavatta A, Montessuit S, Lewis S, Martinou I, Bernasconi L, Bernard A, Mermod JJ, Mazzei $\mathrm{G}$, et al. 1997. Inhibition of Bax channel-forming activity by Bcl-2. Science 277: 370-372.

Arnoult D, Gaume B, Karbowski M, Sharpe JC, Cecconi F, Youle RJ. 2003. Mitochondrial release of AIF and EndoG requires caspase activation downstream of Bax/Bak-mediated permeabilization. EMBO J 22: 4385-4399.

Bao Q, Lu W, Rabinowitz JD, Shi Y. 2007. Calcium blocks formation of apoptosome by preventing nucleotide exchange in Apaf-1. Mol Cell 25: 181-192.

Basanez G, Nechushtan A, Drozhinin O, Chanturiya A, Choe E, Tutt S, Wood KA, Hsu Y, Zimmberberg J, Youle RJ. 1999. Bax, but not Bcl- $\mathrm{X}_{\mathrm{L}}$, decreases the lifetime of planar phospholipid bilayer membranes at subnanomolar concentrations. Proc Natl Acad Sci 96: 5492-5497.

Basanez G, Sharpe JC, Galanis J, Brandt TB, Hardwick JM, Zimmerberg J. 2002. Bax-type apoptotic proteins porate pure lipid bilayers through a mechanism sensitive to intrinsic monolayer curvature. J Biol Chem 277: 4936049365.

Beere HM, Wolf BB, Cain K, Mosser DD, Mahboubi A, Kuwana T, Tailor P, Morimoto RI, Cohen GM, Green DR. 2000. Heat-shock protein 70 inhibits apoptosis by preventing recruitment of procaspase-9 to the Apaf-1 apoptosome. Nat Cell Biol 2: 469-475.

Bender CE, Fitzgerald P, Tait SW, Llambi F, McStay GP, Tupper DO, Pellettieri J, Sanchez Alvarado A, Salvesen GS, Green DR. 2012. Mitochondrial pathway of apoptosis is ancestral in metazoans. Proc Natl Acad Sci 109: 49044909.

Bhola PD, Mattheyses AL, Simon SM. 2009. Spatial and temporal dynamics of mitochondrial membrane permeability waves during apoptosis. Biophys J 97: 2222-2231.

Borutaite V, Brown GC. 2007. Mitochondrial regulation of caspase activation by cytochrome oxidase and tetramethylphenylenediamine via cytosolic cytochrome $c$ redox state. J Biol Chem 282: 31124-31130.

Bratton SB, Salvesen GS. 2010. Regulation of the Apaf-1caspase-9 apoptosome. J Cell Sci 123: 3209-3214.

Cain K, Langlais C, Sun XM, Brown DG, Cohen GM. 2001. Physiological concentrations of $\mathrm{K}^{+}$inhibit cytochrome $c$-dependent formation of the apoptosome. J Biol Chem 276: 41985-41990.

Chandra D, Bratton SB, Person MD, Tian Y, Martin AG, Ayres M, Fearnhead HO, Gandhi V, Tang DG. 2006. In- tracellular nucleotides act as critical prosurvival factors by binding to cytochrome $c$ and inhibiting apoptosome. Cell 125: 1333-1346.

Chautan M, Chazal G, Cecconi F, Gruss P, Golstein P. 1999. Interdigital cell death can occur through a necrotic and caspase-independent pathway. Curr Biol 9: 967-970.

Cheung EC, Joza N, Steenaart NA, McClellan KA, Neuspiel M, McNamara S, MacLaurin JG, Rippstein P, Park DS, Shore GC, et al. 2006. Dissociating the dual roles of apoptosis-inducing factor in maintaining mitochondrial structure and apoptosis. EMBO J 25: 4061-4073.

Chew SK, Chen P, Link N, Galindo KA, Pogue K, Abrams JM. 2009. Genome-wide silencing in Drosophila captures conserved apoptotic effectors. Nature 460: 123-127.

Colell A, Ricci JE, Tait S, Milasta S, Maurer U, BouchierHayes L, Fitzgerald P, Guio-Carrion A, Waterhouse NJ, Li CW, et al. 2007. GAPDH and autophagy preserve survival after apoptotic cytochrome $c$ release in the absence of caspase activation. Cell 129: 983-997.

Crompton M. 1999. The mitochondrial permeability transition pore and its role in cell death. Biochem J 341: 233 249.

Czabotar PE, Westphal D, Dewson G, Ma S, Hockings C, Fairlie WD, Lee EF, Yao S, Robin AY, Smith BJ, et al. 2013. Bax crystal structures reveal how $\mathrm{BH} 3$ domains activate Bax and nucleate its oligomerization to induce apoptosis. Cell 152: 519-531.

Deshmukh M, Johnson EM Jr. 1998. Evidence of a novel event during neuronal death: Development of competence-to-die in response to cytoplasmic cytochrome $c$. Neuron 21: 695-705.

Dewson G, Kratina T, Sim HW, Puthalakath H, Adams JM, Colman PM, Kluck RM. 2008. To trigger apoptosis, Bak exposes its $\mathrm{BH} 3$ domain and homodimerizes via BH3:groove interactions. Mol Cell 30: 369-380.

Dewson G, Kratina T, Czabotar P, Day CL, Adams JM, Kluck RM. 2009. Bak activation for apoptosis involves oligomerization of dimers via their $\alpha 6$ helices. Mol Cell 36: 696-703.

Dewson G, Ma S, Frederick P, Hockings C, Tan I, Kratina T, Kluck RM. 2012. Bax dimerizes via a symmetric BH3:groove interface during apoptosis. Cell Death Differ 19: $661-670$.

Du C, Fang M, Li Y, Li L, Wang X. 2000. Smac, a mitochondrial protein that promotes cytochrome $c$-dependent caspase activation by eliminating IAP inhibition. Cell 102: $33-42$.

Eskes R, Desagher S, Antonsson B, Martinou JC. 2000. Bid induces the oligomerization and insertion of Bax into the outer mitochondrial membrane. Mol Cell Biol 20: 929935.

Estaquier J, Arnoult D. 2007. Inhibiting Drp1-mediated mitochondrial fission selectively prevents the release of $\mathrm{cy}-$ tochrome $c$ during apoptosis. Cell Death Differ 14: $1086-$ 1094.

Ferraro E, Pulicati A, Cencioni MT, Cozzolino M, Navoni F di Martino S, Nardacci R, Carri MT, Cecconi F. 2008. Apoptosome-deficient cells lose cytochrome $c$ through proteasomal degradation but survive by autophagy-dependent glycolysis. Mol Biol Cell 19: 3576-3588. 
Flanagan L, Sebastia J, Tuffy LP, Spring A, Lichawska A, Devocelle M, Prehn JH, Rehm M. 2010. XIAP impairs Smac release from the mitochondria during apoptosis. Cell Death Diff 1: e49.

Frezza C, Cipolat S, Martins de Brito O, Micaroni M, Beznoussenko GV, Rudka T, Bartoli D, Polishuck RS, Danial NN, De Strooper B, et al. 2006. OPAl controls apoptotic cristae remodeling independently from mitochondrial fusion. Cell 126: 177-189.

Garcia-Perez C, Roy SS, Naghdi S, Lin X, Davies E, Hajnoczky G. 2012. Bid-induced mitochondrial membrane permeabilization waves propagated by local reactive oxygen species (ROS) signaling. Proc Natl Acad Sci 109: 4497-4502.

Gavathiotis E, Suzuki M, Davis ML, Pitter K, Bird GH, Katz SG, Tu HC, Kim H, Cheng EH, Tjandra N, et al. 2008. BAX activation is initiated at a novel interaction site. Nature 455: 1076-1081.

Gavathiotis E, Reyna DE, Davis ML, Bird GH, Walensky LD. 2010. BH3-triggered structural reorganization drives the activation of proapoptotic BAX. Mol Cell 40: 481-492.

George NM, Evans JJ, Luo X. 2007. A three-helix homooligomerization domain containing $\mathrm{BH} 3$ and $\mathrm{BH} 1$ is responsible for the apoptotic activity of Bax. Genes Dev 21: 1937-1948.

Germain M, Mathai JP, McBride HM, Shore GC. 2005. Endoplasmic reticulum BIK initiates DRP1-regulated remodelling of mitochondrial cristae during apoptosis. EMBO J 24: 1546-1556.

Gillick K, Crompton M. 2008. Evaluating cytochrome $c$ diffusion in the intermembrane spaces of mitochondria during cytochrome $c$ release. J Cell Sci 121: 618-626.

Goemans CG, Boya P, Skirrow CJ, Tolkovsky AM. 2008. Intra-mitochondrial degradation of Tim 23 curtails the survival of cells rescued from apoptosis by caspase inhibitors. Cell Death Differ 15: 545-554.

Goldstein JC, Waterhouse NJ, Juin P, Evan GI, Green DR. 2000. The coordinate release of cytochrome $c$ during apoptosis is rapid, complete and kinetically invariant. Nat Cell Biol 2: 156-162.

Gray MW. 2012. Mitochondrial evolution. Cold Spring Harb Perspect Biol 4: a011403.

Green DR. 2011. Means to an end: Apoptosis and other cell death mechanisms. Cold Spring Harbor Laboratory Press, Cold Spring Harbor, NY.

Hao Z, Duncan GS, Chang CC, Elia A, Fang M, Wakeham A, Okada H, Calzascia T, Jang Y, You-Ten A, et al. 2005. Specific ablation of the apoptotic functions of cytochrome $c$ reveals a differential requirement for cytochrome $c$ and Apaf- 1 in apoptosis. Cell 121: 579-591.

Hardwick JM, Polster BM. 2002. Bax, along with lipid conspirators, allows cytochrome $c$ to escape mitochondria. Mol Cell 10: 963-965.

Hoffarth S, Zitzer A, Wiewrodt R, Hahnel PS, Beyer V, Kreft A, Biesterfeld S, Schuler M. 2008. pp32/PHAPI determines the apoptosis response of non-small-cell lung cancer. Cell Death Differ 15: 161-170.

Hsu YT, Wolter KG, Youle RJ. 1997. Cytosol-to-membrane redistribution of Bax and Bcl- $\mathrm{X}_{\mathrm{L}}$ during apoptosis. Proc Natl Acad Sci 94: 3668-3672.
Ishihara N, Nomura M, Jofuku A, Kato H, Suzuki SO, Masuda K, Otera H, Nakanishi Y, Nonaka I, Goto Y, et al. 2009. Mitochondrial fission factor Drp1 is essential for embryonic development and synapse formation in mice. Nat Cell Biol 11: 958-966.

James ER, Green DR. 2002. Infection and the origins of apoptosis. Cell Death Differ 9: 355-357.

Jiang X, Kim HE, Shu H, Zhao Y, Zhang H, Kofron J, Donnelly J, Burns D, Ng SC, Rosenberg S, et al. 2003. Distinctive roles of PHAP proteins and prothymosin- $\alpha$ in a death regulatory pathway. Science 299: 223-226.

Jones JM, Datta P, Srinivasula SM, Ji W, Gupta S, Zhang Z, Davies E, Hajnoczky G, Saunders TL, Van Keuren ML, et al. 2003. Loss of Omi mitochondrial protease activity causes the neuromuscular disorder of mnd 2 mutant mice. Nature 425: 721-727.

Jones S, Zhang X, Parsons DW, Lin JC, Leary RJ, Angenendt P, Mankoo P, Carter, Kamiyama H, Jimeno A, et al. 2008. Core signaling pathways in human pancreatic cancers revealed by global genomic analyses. Science 321: 1801-1806.

Jost PJ, Grabow S, Gray D, McKenzie MD, Nachbur U, Huang DC, Bouillet P, Thomas HE, Bomer C, Silke J, et al. 2009. XIAP discriminates between type I and type II FAS-induced apoptosis. Nature 460: 1035-1039.

Khodjakov A, Rieder C, Mannella CA, Kinnally KW. 2004. Laser micro-irradiation of mitochondria: Is there an amplified mitochondrial death signal in neural cells? Mitochondrion 3: 217-227.

Kim HE, Jiang X, Du F, Wang X. 2008. PHAPI, CAS, and Hsp70 promote apoptosome formation by preventing Apaf-1 aggregation and enhancing nucleotide exchange on Apaf-1. Mol Cell 30: 239-247.

Kim J, Parrish AB, Kurokawa M, Matsuura K, Freel CD, Andersen JL, Johnson CE, Kornbluth S. 2012. Rsk-medi-

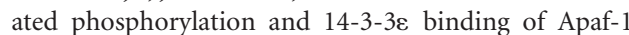
suppresses cytochrome $c$-induced apoptosis. $E M B O J$ 31: 1279-1292.

Kluck RM, Martin SJ, Hoffman BM, Zhou JS, Green DR, Newmeyer DD. 1997. Cytochrome $c$ activation of CPP32like proteolysis plays a critical role in a Xenopus cell-free apoptosis system. EMBO J 16: 4639-4649.

Kuwana T, Mackey MR, Perkins G, Ellisman MH, Latterich M, Schneiter R, Green DR, Newmeyer DD. 2002. Bid, Bax, and lipids cooperate to form supramolecular openings in the outer mitochondrial membrane. Cell 111: $331-342$.

Lartigue L, Medina C, Schembri L, Chabert P, Zanese M, Tomasello F, Dalibart R, Thoraval D, Crouzet M, Ichas F, et al. 2008. An intracellular wave of cytochrome $c$ propagates and precedes Bax redistribution during apoptosis. JCell Sci 121: 3515-3523.

Lartigue L, Kushnareva Y, Seong Y, Lin H, Faustin B, Newmeyer DD. 2009. Caspase-independent mitochondrial cell death results from loss of respiration, not cytotoxic protein release. Mol Biol Cell 20: 4871-4884.

Lavallard VJ, Pradelli LA, Paul A, Beneteau M, Jacquel A, Auberger P, Ricci JE. 2009. Modulation of caspase-independent cell death leads to resensitization of imatinib mesylate-resistant cells. Cancer Res 69: 3013-3020.

Lee EF, Clarke OB, Evangelista M, Feng Z, Speed TP, Tchoubrieva EB, Strasser A, Kalinna BH, Colman PM, Fairlie 
S.W.G. Tait and D.R. Green

WD. 2011. Discovery and molecular characterization of a Bcl-2-regulated cell death pathway in schistosomes. Proc Natl Acad Sci 108: 6999-7003.

Leshchiner ES, Braun CR, Bird GH, Walensky LD. 2013. Direct activation of full-length proapoptotic BAK. Proc Natl Acad Sci 110: E986-E995.

Li K, Li Y, Shelton JM, Richardson JA, Spencer E, Chen ZJ, Wang X, Williams RS. 2000. Cytochrome $c$ deficiency causes embryonic lethality and attenuates stress-induced apoptosis. Cell 101: 389-399.

Lindsten T, Ross AJ, King A, Zong WX, Rathmell JC, Shiels HA, Ulrich E, Waymire KG, Mahar P, Frauwirth K, et al. 2000. The combined functions of proapoptotic Bcl-2 family members bak and bax are essential for normal development of multiple tissues. Mol Cell 6: 1389-1399.

Malladi S, Challa-Malladi M, Fearnhead HO, Bratton SB. 2009. The Apaf- $1^{*}$ procaspase- 9 apoptosome complex functions as a proteolytic-based molecular timer. EMBO J 28: 1916-1925.

Martinez-Caballero S, Dejean LM, Kinnally MS, Oh KJ, Mannella CA, Kinnally KW. 2009. Assembly of the mitochondrial apoptosis-induced channel, MAC. J Biol Chem 284: 12235-12245.

Martinou I, Desagher S, Eskes R, Antonsson B, Andre E Fakan S, Martinou JC. 1999. The release of cytochrome $c$ from mitochondria during apoptosis of NGF-deprived sympathetic neurons is a reversible event. J Cell Biol 144: 883-889.

Martins LM, Morrison A, Klupsch K, Fedele V, Moisoi N, Teismann P, Albuin A, Grau E, Geppert M, Livi GP, et al. 2004. Neuroprotective role of the Reaper-related serine protease $\mathrm{HtrA} 2 / \mathrm{Omi}$ revealed by targeted deletion in mice. Mol Cell Biol 24: 9848-9862.

Matapurkar A, Lazebnik Y. 2006. Requirement of cytochrome $c$ for apoptosis in human cells. Cell Death Differ 13: 2062-2067.

Mei Y, Yong J, Liu H, Shi Y, Meinkoth J, Dreyfuss G, Yang X. 2010. tRNA binds to cytochrome $c$ and inhibits caspase activation. Mol Cell 37: 668-678.

Moldoveanu T, Grace CR, Llambi F, Nourse A, Fitzgerald P, Gehring K, Kriwacki RW, Green DR. 2013. BID-induced structural changes in BAK promote apoptosis. Nat Struct Mol Biol doi: 10.1038/nsmb.2563.

Montessuit S, Somasekharan SP, Terrones O, Lucken-Ardjomande S, Herzig S, Schwarzenbacher R, Manstein DJ, Bossy-Wetzel E, Basanez G, Meda P, et al. 2010. Membrane remodeling induced by the dynamin-related protein Drp1 stimulates Bax oligomerization. Cell 142: 889901.

Muchmore SW, Sattler M, Liang H, Meadows RP, Harlan JE, Yoon HS, Nettesheim D, Chang BS, Thompson CB, Wong SL, et al. 1996. X-ray and NMR structure of human Bcl- $\mathrm{X}_{\mathrm{L}}$, an inhibitor of programmed cell death. Nature 381: 335-341.

Munoz-Pinedo C, Guio-Carrion A, Goldstein JC, Fitzgerald P, Newmeyer DD, Green DR. 2006. Different mitochondrial intermembrane space proteins are released during apoptosis in a manner that is coordinately initiated but can vary in duration. Proc Natl Acad Sci 103: $11573-$ 11578.
Narendra D, Tanaka A, Suen DF, Youle RJ. 2008. Parkin is recruited selectively to impaired mitochondria and promotes their autophagy. J Cell Biol 183: 795-803.

Niimi S, Arakawa-Takeuchi S, Uranbileg B, Park JH, Jinno S, Okayama H. 2012. Cdc6 protein obstructs apoptosome assembly and consequent cell death by forming stable complexes with activated Apaf-1 molecules. J Biol Chem 287: 18573-18583.

Oberst A, Bender C, Green DR. 2008. Living with death: The evolution of the mitochondrial pathway of apoptosis in animals. Cell Death Differ 15: 1139-1146.

Okada H, Suh WK, Jin J, Woo M, Du C, Elia A, Duncan GS, Wakeham A, Itie A, Lowe SW, et al. 2002. Generation and characterization of Smac/DIABLO-deficient mice. $\mathrm{Mol}$ Cell Biol 22: 3509-3517.

Ott M, Robertson JD, Gogvadze V, Zhivotovsky B, Orrenius S. 2002. Cytochrome $c$ release from mitochondria proceeds by a two-step process. Proc Natl Acad Sci 99: 12591263.

Pan Z, Voehringer DW, Meyn RE. 1999. Analysis of redox regulation of cytochrome $c$-induced apoptosis in a cellfree system. Cell Death Differ 6: 683-688.

Pandey P, Saleh A, Nakazawa A, Kumar S, Srinivasula SM, Kumar V, Weichselbaum R, Nalin C, Alnemri ES, Kufe D, et al. 2000. Negative regulation of cytochrome $c$-mediated oligomerization of Apaf- 1 and activation of procaspase- 9 by heat shock protein 90. EMBO J 19: 4310-4322.

Parone PA, James DI, Da Cruz S, Mattenberger Y, Donze O, Barja F, Martinou JC. 2006. Inhibiting the mitochondrial fission machinery does not prevent Bax/Bak-dependent apoptosis. Mol Cell Biol 26: 7397-7408.

Peixoto PM, Ryu SY, Bombrun A, Antonsson B, Kinnally KW. 2009. MAC inhibitors suppress mitochondrial apoptosis. Biochem J 423: 381-387.

Polster BM, Basanez G, Etxebarria A, Hardwick JM, Nicholls DG. 2005. Calpain I induces cleavage and release of apoptosis-inducing factor from isolated mitochondria. $J$ Biol Chem 280: 6447-6454.

Potts PR, Singh S, Knezek M, Thompson CB, Deshmukh M. 2003. Critical function of endogenous XIAP in regulating caspase activation during sympathetic neuronal apoptosis. J Cell Biol 163: 789-799.

Potts MB, Vaughn AE, McDonough H, Patterson C, Deshmukh M. 2005. Reduced Apaf-1 levels in cardiomyocytes engage strict regulation of apoptosis by endogenous XIAP. J Cell Biol 171: 925-930.

Rehm M, Dussmann H, Prehn JH. 2003. Real-time single cell analysis of Smac/DIABLO release during apoptosis J Cell Biol 162: 1031-1043.

Rehm M, Huber HJ, Hellwig CT, Anguissola S, Dussmann H, Prehn JH. 2009. Dynamics of outer mitochondrial membrane permeabilization during apoptosis. Cell Death Differ 16: 613-623.

Ryoo HD, Baehrecke EH. 2010. Distinct death mechanisms in Drosophila development. Curr Opin Cell Biol 22: 889895.

Saleh A, Srinivasula SM, Balkir L, Robbins PD, Alnemri ES. 2000. Negative regulation of the Apaf-1 apoptosome by Hsp70. Nat Cell Biol 2: 476-483. 
Schafer ZT, Kornbluth S. 2006. The apoptosome: Physiological, developmental, and pathological modes of regulation. Dev Cell 10: 549-561.

Schafer B, Quispe J, Choudhary V, Chipuk JE, Ajero TG, Du H, Schneiter R, Kuwana T. 2009. Mitochondrial outer membrane proteins assist Bid in Bax-mediated lipidic pore formation. Mol Biol Cell 20: 2276-2285.

Scorrano L, Ashiya M, Buttle K, Weiler S, Oakes SA, Mannella CA, Korsmeyer SJ. 2002. A distinct pathway remodels mitochondrial cristae and mobilizes cytochrome $c$ during apoptosis. Dev Cell 2: 55-67.

Sun MG, Williams J, Munoz-Pinedo C, Perkins GA, Brown JM, Ellisman MH, Green DR, Frey TG. 2007. Correlated three-dimensional light and electron microscopy reveals transformation of mitochondria during apoptosis. Nat Cell Biol 9: 1057-1065.

Suzuki M, Youle RJ, Tjandra N. 2000. Structure of Bax: Coregulation of dimer formation and intracellular localization. Cell 103: 645-654.

Suzuki Y, Imai Y, Nakayama H, Takahashi K, Takio K, Takahashi R. 2001. A serine protease, HtrA2, is released from the mitochondria and interacts with XIAP, inducing cell death. Mol Cell 8: 613-621.

Tait SW, Green DR. 2008. Caspase-independent cell death: Leaving the set without the final cut. Oncogene 27: 64526461.

Tait SW, Parsons MJ, Llambi F, Bouchier-Hayes L, Connell S, Munoz-Pinedo C, Green DR. 2010. Resistance to caspase-independent cell death requires persistence of intact mitochondria. Dev Cell 18: 802-813.

Tan FJ, Fire AZ, Hill RB. 2007. Regulation of apoptosis by C. elegans CED-9 in the absence of the C-terminal transmembrane domain. Cell Death Differ 14: 1925-1935.

Vahsen N, Cande C, Briere JJ, Benit P, Joza N, Larochette N, Mastroberardino PG, Pequignot MO, Casares N, Lazar V, et al. 2004. AIF deficiency compromises oxidative phosphorylation. EMBO J 23: 4679-4689.
Vaughn AE, Deshmukh M. 2008. Glucose metabolism inhibits apoptosis in neurons and cancer cells by redox inactivation of cytochrome c. Nature Cell Biol 10: 1477-1483.

Verhagen AM, Ekert PG, Pakusch M, Silke J, Connolly LM, Reid GE, Moritz RL, Simpson RJ, Vaux DL. 2000. Identification of DIABLO, a mammalian protein that promotes apoptosis by binding to and antagonizing IAP proteins. Cell 102: 43-53.

Wei MC, Lindsten T, Mootha VK, Weiler S, Gross A, Ashiya M, Thompson CB, Korsmeyer SJ. 2000. tBID, a membrane-targeted death ligand, oligomerizes BAK to release cytochrome c. Genes Dev 14: 2060-2071.

Wei MC, Zong WX, Cheng EH, Lindsten T, Panoutsakopoulou V, Ross AJ, Roth KA, MacGregor GR, Thompson CB, Korsmeyer SJ. 2001. Proapoptotic BAX and BAK: A requisite gateway to mitochondrial dysfunction and death. Science 292: 727-730.

Wright KM, Linhoff MW, Potts PR, Deshmukh M. 2004. Decreased apoptosome activity with neuronal differentiation sets the threshold for strict IAP regulation of apoptosis. J Cell Biol 167: 303-313.

Yamaguchi R, Lartigue L, Perkins G, Scott RT, Dixit A, Kushnareva Y, Kuwana T, Ellisman MH, Newmeyer DD. 2008. Opa1-mediated cristae opening is Bax/Bak and BH3 dependent, required for apoptosis, and independent of Bak oligomerization. Mol Cell 31: 557-569.

Yoshida H, Kong YY, Yoshida R, Elia AJ, Hakem A, Hakem R, Penninger JM, Mak TW. 1998. Apaf1 is required for mitochondrial pathways of apoptosis and brain development. Cell 94: 739-750.

Youle RJ, Strasser A. 2008. The BCL-2 protein family: Opposing activities that mediate cell death. Nat Rev Mol Cell Biol 9: 47-59.

Zhuang M, Guan S, Wang H, Burlingame AL, Wells JA. 2013. Substrates of IAP ubiquitin ligases identified with a designed orthogonal E3 ligase, the NEDDylator. $\mathrm{Mol}$ Cell 49: 273-282. 


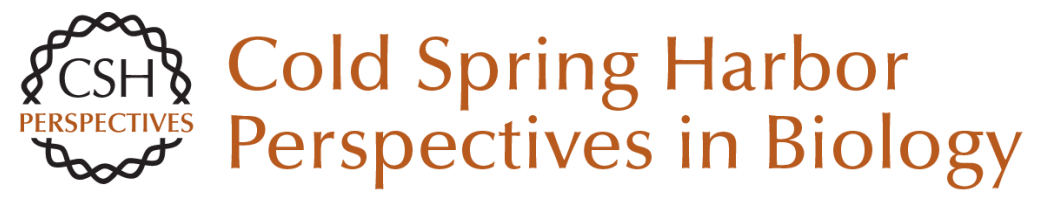

\section{Mitochondrial Regulation of Cell Death}

Stephen W.G. Tait and Douglas R. Green

Cold Spring Harb Perspect Biol 2013; doi: 10.1101/cshperspect.a008706

Subject Collection Cell Survival and Cell Death

Programmed Cell Death in the Evolutionary Race against Bacterial Virulence Factors

Carolyn A. Lacey and Edward A. Miao

The Evolutionary Origins of Programmed Cell

Death Signaling

Kay Hofmann

Regulation of Cell Death and Immunity by XIAP Philipp J. Jost and Domagoj Vucic

Dysregulation of Cell Death in Human Chronic Inflammation

Yue Li, Christoph Klein and Daniel Kotlarz

Cell Death in Plant Immunity

Eugenia Pitsili, Ujjal J. Phukan and Nuria S. Coll

Recent Insights on Inflammasomes, Gasdermin Pores, and Pyroptosis

Nathalia M. de Vasconcelos and Mohamed Lamkanfi

Phagocyte Responses to Cell Death in Flies Andrew J. Davidson and Will Wood

Mechanism and Regulation of

Gasdermin-Mediated Cell Death

Shiyu Xia, Louis Robert Hollingsworth IV and Hao Wu
Cell Death and Neurodegeneration Benjamin J. Andreone, Martin Larhammar and Joseph W. Lewcock

Death Receptors and Their Ligands in Inflammatory Disease and Cancer Alessandro Annibaldi and Henning Walczak

The Killer Pseudokinase Mixed Lineage Kinase Domain-Like Protein (MLKL) James M. Murphy

Neutrophil Extracellular Traps in Host Defense Sabrina Sofia Burgener and Kate Schroder

Cell-Cycle Cross Talk with Caspases and Their Substrates Patrick Connolly, Irmina Garcia-Carpio and Andreas Villunger

Cracking the Cell Death Code Carla V. Rothlin and Sourav Ghosh

BAX, BAK, and BOK: A Coming of Age for the BCL-2 Family Effector Proteins

Tudor Moldoveanu and Peter E. Czabotar

Multitasking Kinase RIPK1 Regulates Cell Death and Inflammation

Kim Newton

For additional articles in this collection, see http://cshperspectives.cshlp.org/cgi/collection/

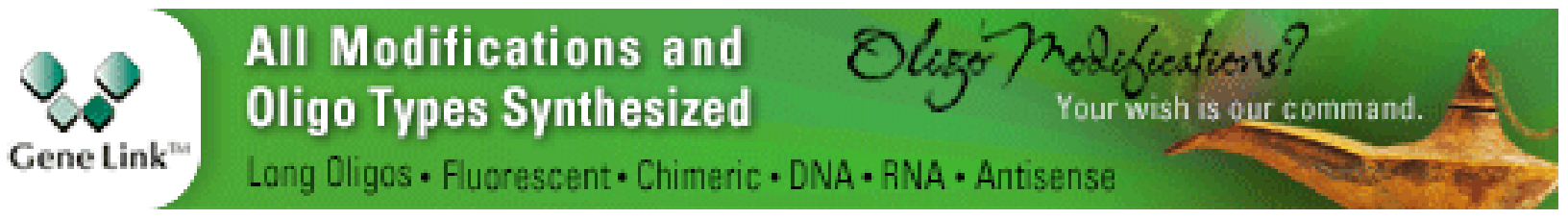

Copyright @ 2013 Cold Spring Harbor Laboratory Press; all rights reserved 
For additional articles in this collection, see http://cshperspectives.cshlp.org/cgi/collection/

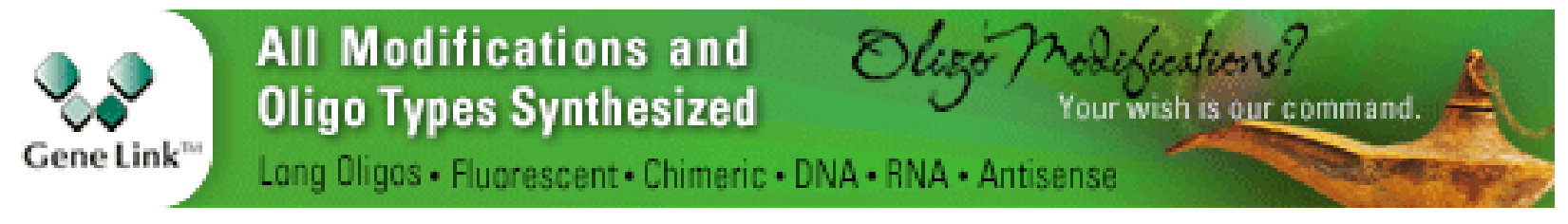

Copyright @ 2013 Cold Spring Harbor Laboratory Press; all rights reserved 